2-15-1999

\title{
[2,3:5,6]Dibenzo[2.2.2]octa-2,5,7-triene (C2/c) and [2,3:5,6]dibenzo[2.2.2]octa-2,5-diene
}

Lary Burrows

John M. Masnovi

Cleveland State University, j.masnovi@csuohio.edu

Ronald J. Baker

Follow this and additional works at: https://engagedscholarship.csuohio.edu/scichem_facpub

Part of the Organic Chemistry Commons

How does access to this work benefit you? Let us know!

\section{Recommended Citation}

Burrows, L., Masnovi, J., \& Baker, R. J. (February 15, 1999). [2,3:5,6]Dibenzo[2.2.2]octa-2,5,7-triene (C2/c) and [2,3:5,6]dibenzo[2.2.2]octa-2,5-diene. Acta Crystallographica Section C: Crystal Structure Communications, 55, 2, 236-239.

This Article is brought to you for free and open access by the Chemistry Department at EngagedScholarship@CSU. It has been accepted for inclusion in Chemistry Faculty Publications by an authorized administrator of EngagedScholarship@CSU. For more information, please contact library.es@csuohio.edu. 
$S=0.997$

2331 reflections

150 parameters

$\mathrm{H}$ atoms treated by a mixture of independent and constrained refinement $w=1 /\left[\sigma^{2}\left(F_{o}^{2}\right)+(0.0739 P)^{2}\right.$ $+0.0414 P]$

where $P=\left(F_{o}^{2}+2 F_{c}^{2}\right) / 3$

Table 1. Selected geometric parameters $\left(\AA,^{\circ}\right)$

$\begin{array}{lllr}\mathrm{O} 1-\mathrm{C} 2 & 1.195(2) & \mathrm{N} 1-\mathrm{C} 9 & 1.358(3) \\ \mathrm{O} 2-\mathrm{C} 2 & 1.342(2) & \mathrm{N} 1-\mathrm{C} 6 & 1.414(2) \\ \mathrm{O} 2-\mathrm{C} 3 & 1.415(2) & \mathrm{C} 1-\mathrm{C} 2 & 1.487(3) \\ \mathrm{O} 3-\mathrm{C} 9 & 1.222(2) & \mathrm{C} 9-\mathrm{C} 10 & 1.503(3) \\ \mathrm{C} 2-\mathrm{O} 2-\mathrm{C} 3 & 117.09(14) & \mathrm{C} 8-\mathrm{C} 3-\mathrm{O} 2 & 119.17(18) \\ \mathrm{C} 9-\mathrm{N} 1-\mathrm{C} 6 & 129.25(17) & \mathrm{C} 7-\mathrm{C} 6-\mathrm{N} 1 & 117.21(17) \\ \mathrm{O} 1-\mathrm{C} 2-\mathrm{O} 2 & 122.39(17) & \mathrm{C} 5-\mathrm{C} 6-\mathrm{N} 1 & 123.69(17) \\ \mathrm{O} 1-\mathrm{C} 2-\mathrm{C} 1 & 126.34(18) & \mathrm{O} 3-\mathrm{C} 9-\mathrm{N} 1 & 123.43(17) \\ \mathrm{O} 2-\mathrm{C} 2-\mathrm{C} 1 & 111.26(16) & \mathrm{O} 3-\mathrm{C} 9-\mathrm{C} 10 & 122.37(17) \\ \mathrm{C} 4-\mathrm{C} 3-\mathrm{O} 2 & 119.12(17) & \mathrm{N} 1-\mathrm{C} 9-\mathrm{C} 10 & 114.19(17) \\ \mathrm{C} 3-\mathrm{O} 2-\mathrm{C} 2-\mathrm{O} 1 & -2.7(3) & \mathrm{C} 9-\mathrm{N} 1-\mathrm{C} 6-\mathrm{C} 7 & -168.3(2) \\ \mathrm{C} 2-\mathrm{O} 2-\mathrm{C} 3-\mathrm{C} 4 & 99.8(2) & \mathrm{C} 9-\mathrm{N} 1-\mathrm{C} 6-\mathrm{C} 5 & 10.3(3) \\ \mathrm{C} 2-\mathrm{O} 2-\mathrm{C} 3-\mathrm{C} 8 & -84.1(2) & \mathrm{C} 6-\mathrm{N} 1-\mathrm{C} 9-\mathrm{O} 3 & -4.8(3)\end{array}$

Table 2. Hydrogen-bonding geometry $\left(\AA,^{\circ}\right)$

$\begin{array}{ccccc}D-\mathrm{H} \cdots A & D-\mathrm{H} & \mathrm{H} \cdots A & D \cdots A & D-\mathrm{H} \cdots A \\ \mathrm{~N} 1-\mathrm{H} I \mathrm{~N} \cdots \mathrm{O} 1^{\mathrm{i}} & 0.86(2) & 2.09(2) & 2.934(2) & 166(1)\end{array}$

Symmetry code: (i) $\frac{5}{2}-x,-\frac{1}{2}+y, \frac{1}{2}-z$.

Methyl-H atoms were modelled in a riding mode and their orientations were found by refining rotation about the $\mathrm{C}$ Me bonds. All other $\mathrm{H}$ atoms were treated isotropically. All calculations were performed on a Silicon Graphics Indy R4600.

Data collection: MSC/AFC Diffractometer Control Software (Molecular Structure Corporation, 1985). Cell refinement: MSC/AFC Diffractometer Control Software. Data reduction: TEXSAN (Molecular Structure Corporation, 1993). Program(s) used to solve structure: SAPI (Fan, 1988). Program(s) used to refine structure: SHELXL97 (Sheldrick, 1997). Software used to prepare material for publication: SHELXL97; TEXSAN.

Supplementary data for this paper are available from the IUCr electronic archives (Reference: BM1270). Services for accessing these data are described at the back of the journal.

\section{References}

Chattaway, F. D. (1931). J. Chem. Soc. pp. 2495-2496.

Chow, A. H. L., Chow, P. K. K., Zhongshan, W. \& Grant, D. J. W. (1985). Int. J. Pharm. 24, 239-258.

Dittert, L. W., Caldwell, H. C., Adams, H. J., Irwin, G. M. \& Swintosky, J. V. (1968). J. Pharm. Sci. 57, 774-780.

Fairbrother, J. E. (1973). Analytical Profiles of Drug Substances, Vol. 3, edited by K. Florey, pp. 1-109. New York: Academic Press.

Fan, H.-F. (1988). SAPI. Structure Analysis Programs with Intelligent Control. Rigaku Corporation, Tokyo, Japan.

Haisa, M., Kashino, S., Kawai, R. \& Maeda, H. (1976). Acta Cryst. B32, 1283-1285.

Haisa, M., Kashino, S. \& Maeda, H. (1974). Acta Cryst. B30, 2510 2512.

Haisa, M., Kashino, S., Ueno, T., Shinozaki, N. \& Matsuzaki, Y. (1980). Acta Cryst. B36, 2306-2311.

Johnson, C. K. (1976). ORTEPII. Report ORNL-5138. Oak Ridge National Laboratory, Tennessee, USA.
Johnson, S. W., Eckert, J., Barthes, M., McMullan, R. K. \& Muller, M. (1995). J. Phys. Chem. 99, 16253-16260.

Molecular Structure Corporation (1985). MSC/AFC Diffractometer Control Softurare. MSC, 3200 Research Forest Drive, The Woodlands, TX 77381, USA.

Molecular Structure Corporation (1993). TEXSAN. Version 1.6. Single Crystal Structure Analysis Package. MSC, 3200 Research Forest Drive, The Woodlands, TX 77381, USA.

Patel, U., Patel, T. C. \& Singh, T. P. (1983). Acta Cryst. C39, 14451447.

Prasad, K. V. R., Ristic, R. I., Sheen, D. B. \& Sherwood. J. N. (1998). Unpublished results.

Sheldrick, G. M. (1997). SHELXL97. Program for the Refinement of Crystal Structures. University of Göttingen, Germany.

Acta Cryst. (1999). C55, 236-239

\section{[2,3:5,6]Dibenzo[2.2.2]octa-2,5,7-triene} $(C 2 / c)$ and $[2,3: 5,6]$ dibenzo[2.2.2]octa-2,5diene†

\section{LaRy Burrows, John Masnovi and Ronald J. BaKer}

Department of Chemistry, Cleveland State University, Cleveland, $O H 44115$, USA. E-mail: j.masnovi@popmail. csuohio.edu

(Received 14 July 1998; accepted 2 October 1998)

\section{Abstract}

Two barrelene homologs are reported. Strain in the bicyclic framework of [2,3:5,6]dibenzo[2.2.2]octa-2,5,7triene, (I) $\left(\mathrm{C}_{16} \mathrm{H}_{12}\right)$, which is manifest in the deviations from ideality of the bond angles in the central bicyclic ring system and compression of the double bond [1.312(3) $\AA$ ], is reduced in the more saturated derivative, [2,3:5,6]dibenzo[2.2.2]octa-2,5-diene, (II) $\left(\mathrm{C}_{16} \mathrm{H}_{14}\right)$, with the corresponding single bond being 1.5380 (19) A. The formation of isomorphs of (I) in both chiral (C2) and achiral $(C 2 / c)$ space groups has implications for asymmetric syntheses involving solid (I) which rely on a non-centrosymmetric space group.

\section{Comment}

Recent controversy concerns the origin of elongated interannular $\mathrm{C}-\mathrm{C}$ single bonds in anthracene and related cycloadducts (Baldridge et al., 1997). We prepared the title compounds, (I) and (II), as the first in a series of compounds designed to investigate features responsible for the anomalous bond properties in these systems. Bond distances and angles within the aromatic rings

† Alternative names: 9,10-dihydro-9,10-ethenoanthracene and 9,10-dihydro-9,10-ethanoanthracene. 
of (I) and (II) were found to be fairly typical. Slight bond alternation is observed in the benzene rings, with the distal aromatic bonds $(\mathrm{C} 2-\mathrm{C} 3$ and $\mathrm{C} 6-\mathrm{C} 7)$ being about $0.02 \AA$ shorter than the proximal bonds (C4a$\mathrm{C} 9 \mathrm{a}$ and $\mathrm{C} 8 \mathrm{a}-\mathrm{C10a})$. The double bond $(\mathrm{C} 11=\mathrm{C} 12)$ in (I) is $1.312(3) \AA$, which is relatively short for a $C=C$ double bond. This agrees with the value of $1.316(4) \AA$ reported for a $C 2$ isomorph of (I), (I $a)$, obtained from ethanol (Trotter \& Wireko, 1990), and the value of 1.312 (3) § for a dichloro derivative (Benites et al., 1997). The corresponding single bond $(\mathrm{C} 11-\mathrm{Cl} 2)$ in (II) is $1.5280(19) \AA, 0.016 \AA$ shorter than the average of the other single bonds $(\mathrm{C} 9-\mathrm{C} 12$ and $\mathrm{C} 10-\mathrm{C} 11)$ involving two $\mathrm{C}$ atoms with $s p^{3}$ hybridization.

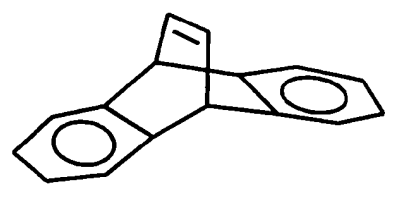

(I)

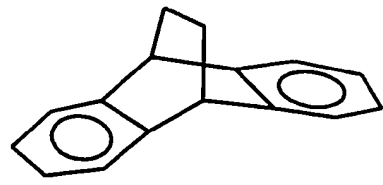

(II)
Bond angles about the central bicyclic system deviate substantially from ideality. The exterior angles (C4$\mathrm{C} 4 \mathrm{a}-\mathrm{C} 10$ and chemical equivalents) average $127.03^{\circ}$ in (I) and $126.80^{\circ}$ in (II), with the interior angles (C9a- $4 \mathrm{a}-\mathrm{C} 10$ and chemical equivalents) being correspondingly smaller [averaging $112.65^{\circ}$ in (I) and $113.09^{\circ}$ in (II)]. The tetrahedral angles also exhibit significant distortion: $\mathrm{C} 8 \mathrm{a}-\mathrm{C} 9-\mathrm{C} 9 \mathrm{a}$ and $\mathrm{C} 4 \mathrm{a}-\mathrm{C} 10-$ Cl0a average $104.40^{\circ}$ in (I) and $107.62^{\circ}$ in (II), and $\mathrm{C} 8 \mathrm{a}-\mathrm{C} 9-\mathrm{C} 12, \mathrm{C} 9 \mathrm{a}-\mathrm{C} 9-\mathrm{C} 12, \mathrm{C} 4 \mathrm{a}-\mathrm{C} 10-\mathrm{C} 11$ and $\mathrm{ClOa}-\mathrm{C} 10-\mathrm{C} 11$ average $106.02^{\circ}$ in (I) and $106.48^{\circ}$ in (II). The angles $\mathrm{C} 10-\mathrm{C} 11-\mathrm{C} 12$ and $\mathrm{C} 9-\mathrm{C} 12-\mathrm{C} 11$ about the double bond of (I) average $114.3^{\circ}$, compared with $109.65^{\circ}$ for $\mathrm{C} 10-\mathrm{C} 11-\mathrm{C} 12$ and $\mathrm{C} 9-\mathrm{C} 12-\mathrm{C} 11$ for the single bond of (II). Bond distances and angles for the two isomorphs of (I), namely, (I) and (Ia) (Trotter \& Wireko, 1990), are in good agreement.

These results indicate the presence of significant strain in the bicyclic framework of (I), which is reduced in the more saturated derivative, (II). The high degree of strain in (I) is manifest most obviously in the deviations from ideality of the bond angles in the central bicyclic ring system, and compression of the $\mathrm{C} 11=\mathrm{C} 12$ double bond is also apparent.

Finally, the formation of a $C 2 / c$ isomorph of (I) has implications for asymmetric syntheses involving solid (I) which rely on a non-centrosymmetric space group (Garcia-Garibay et al., 1988). Concern that (I) and the $C 2$ structure previously reported might be identical can be dismissed, based upon the centrosymmetric relationship between symmetry-related molecules in $C 2 / c$, which is not present in C2. Comparison of the packing of the two allotropes reveals a chiral distribution of molecules in $C 2$. The existence of

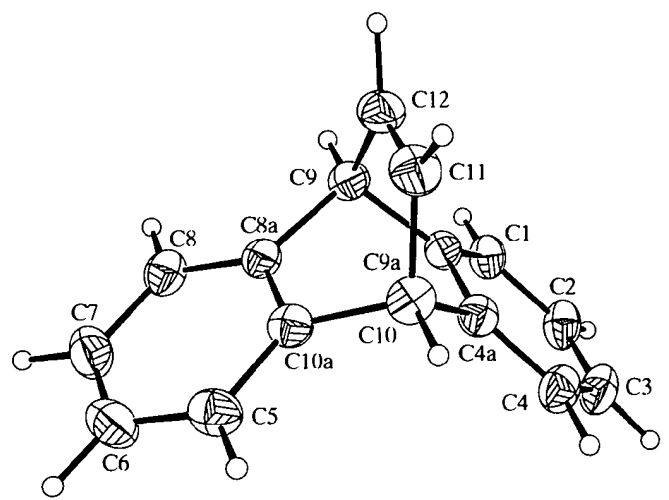

Fig. 1. ORTEPII (Johnson, 1976) drawing of (I), showing the atom-labeling scheme. Displacement ellipsoids are shown at $30 \%$ probability.

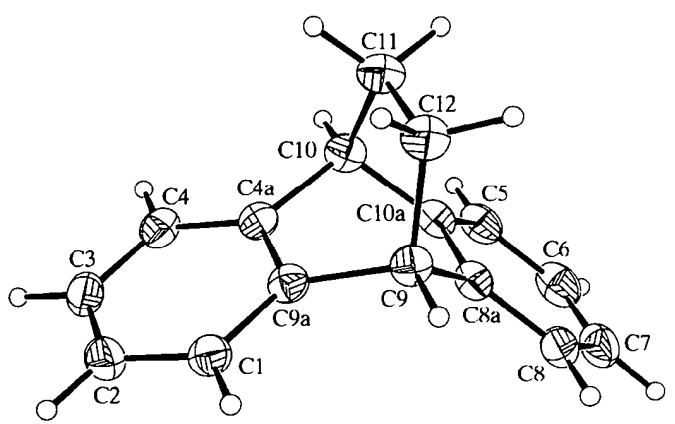

Fig. 2. ORTEPII (Johnson, 1976) drawing of (II), showing the atom-labeling scheme. Displacement ellipsoids are shown at $30 \%$ probability.

centrosymmetric and non-centrosymmetric allotropes suggests that caution should be exercised in verifying the space group when attempting a chiral synthesis using crystals of this compound.

\section{Experimental}

[2,3:5,6]Dibenzo[2.2.2]octa-2,5,7-triene, (I), was prepared by Diels-Alder cycloaddition of anthracene and maleic anhydride in refluxing xylene (82\% yield; Mayo et al., 1989), followed by hydrolysis to the dicarboxylic acid (Cimarusti \& Wolinski, 1968 ) and didecarboxylation with lead tetraacetate in benzene (11\% yield; Miller \& Stiles, 1963). The product was purified by column chromatography on activity I Woelm alumina, eluting fractionally with hexane and dichloromethane. [2,3:5,6]Dibenzo[2.2.2] octa-2,5-diene, (II), was prepared by hydrogenation of (I) at $1 \mathrm{~atm}(1 \mathrm{~atm}=101325 \mathrm{~Pa})$ using $10 \% \mathrm{Pd} / \mathrm{C}$ in ethyl acetate (99\% yield). Single crystals of (I) and (II) were obtained by crystallization from ethyl acetate.

\section{Compound (I)}

Crystal data

$\mathrm{C}_{16} \mathrm{H}_{12}$

$M_{r}=204.27$

Mo $K \alpha$ radiation

$\lambda=0.7093 \AA$ 
Monoclinic

$C 2 / c$

$a=14.4077$ (11) $\AA$

$b=8.0758(7) \AA$

$c=19.0278(8) \AA$

$\beta=92.950(5)^{\circ}$

$V=2211.0(3) \AA^{3}$

$Z=8$

$D_{x}=1.227 \mathrm{Mg} \mathrm{m}^{-3}$

$D_{m}$ not measured

Data collection

Nonius CAD-4 diffractometer

$\omega$-scans

Absorption correction: none

2024 measured reflections

1942 independent reflections 1519 reflections with

$I_{\text {net }}>2 \sigma\left(I_{\text {net }}\right)$

\section{Refinement}

Refinement on $F$

$R=0.038$

$w R=0.042$

$S=2.06$

1517 reflections

146 parameters

$\mathrm{H}$ atoms: see below

$w=1 /\left[\sigma^{2}(F)+0.0002 F^{2}\right]$

$(\Delta / \sigma)_{\max }<0.001$
Cell parameters from 25 reflections

$\theta=7.8-14.3^{\circ}$

$\mu=0.069 \mathrm{~mm}^{-1}$

$T=293 \mathrm{~K}$

Cube

$0.53 \times 0.53 \times 0.53 \mathrm{~mm}$

Colorless

$$
\begin{aligned}
& R_{\text {int }}=0.006 \\
& \theta_{\max }=25^{\circ} \\
& h=-17 \rightarrow 16 \\
& k=0 \rightarrow 9 \\
& l=0 \rightarrow 22
\end{aligned}
$$

3 standard reflections frequency: $120 \mathrm{~min}$ intensity decay: none

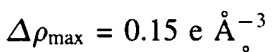

$\Delta \rho_{\min }=-0.12 \mathrm{e} \AA^{-3}$

Extinction correction: Larson (1970)

Extinction coefficient: $1.21(12)$

Scattering factors from International Tables for $X$-ray Crystallography (Vol. IV)

Table 1. Selected geometric parameters $\left(\AA,^{\circ}\right)$ for $(I)$

$\begin{array}{llll}\mathrm{C} 2-\mathrm{C} 3 & 1.373(3) & \mathrm{C} 9-\mathrm{C} 9 \mathrm{a} & 1.527(2) \\ \mathrm{C} 4 \mathrm{a}-\mathrm{C} 9 \mathrm{a} & 1.397(2) & \mathrm{C} 9-\mathrm{C} 12 & 1.528(2) \\ \mathrm{C} 4 \mathrm{a}-\mathrm{C} 10 & 1.523(2) & \mathrm{C} 10-\mathrm{C} 10 \mathrm{a} & 1.520(2) \\ \mathrm{C} 6-\mathrm{C} 7 & 1.373(3) & \mathrm{C} 10-\mathrm{C} 11 & 1.523(2) \\ \mathrm{C} 8 \mathrm{a}-\mathrm{C} 9 & 1.522(2) & \mathrm{C} 11-\mathrm{C} 12 & 1.312(3) \\ \mathrm{C} 8 \mathrm{a}-\mathrm{Cl0a} & 1.392(2) & & \\ \mathrm{C} 4-\mathrm{C} 4 \mathrm{a}-\mathrm{C} 10 & 126.95(14) & \mathrm{C} 4 \mathrm{a}-\mathrm{C} 9 \mathrm{a}-\mathrm{C} 9 & 112.34(12) \\ \mathrm{C} 9 \mathrm{a}-\mathrm{C} 4 \mathrm{a}-\mathrm{C} 10 & 112.80(13) & \mathrm{C} 4 \mathrm{a}-\mathrm{C} 10-\mathrm{C} 10 \mathrm{a} & 104.23(11) \\ \mathrm{C} 8-\mathrm{C} 8 \mathrm{a}-\mathrm{C} 9 & 126.98(14) & \mathrm{C} 4 \mathrm{a}-\mathrm{C} 10-\mathrm{C} 11 & 106.11(13) \\ \mathrm{C} 9-\mathrm{C} 8 \mathrm{a}-\mathrm{C} 10 \mathrm{a} & 112.68(13) & \mathrm{C} 10 \mathrm{a}-\mathrm{C} 10-\mathrm{C} 11 & 106.10(13) \\ \mathrm{C} 8 \mathrm{a}-\mathrm{C} 9-\mathrm{C} 9 \mathrm{a} & 104.57(12) & \mathrm{C} 5-\mathrm{C} 10 \mathrm{a}-\mathrm{Cl} & 127.03(14) \\ \mathrm{C} 8 \mathrm{a}-\mathrm{C} 9-\mathrm{C} 12 & 105.97(12) & \mathrm{C} 8 \mathrm{a}-\mathrm{C} 10 \mathrm{a}-\mathrm{C} 10 & 112.79(13) \\ \mathrm{C} 9 \mathrm{a}-\mathrm{C} 9-\mathrm{C} 12 & 105.90(12) & \mathrm{C} 10-\mathrm{C} 11-\mathrm{C} 12 & 114.46(14) \\ \mathrm{C} 1-\mathrm{C} 9 \mathrm{a}-\mathrm{C} 9 & 127.17(13) & \mathrm{C} 9-\mathrm{C} 12-\mathrm{C} 11 & 114.15(14)\end{array}$

\section{Compound (II)}

Crystal data

$\mathrm{C}_{16} \mathrm{H}_{14}$

$M_{r}=206.28$

Monoclinic

$P 2_{1} / c$

$a=10.6880(10) \AA$

$b=6.3449(6) \AA$

$c=16.978(3) \AA$

$\beta=104.620(10)^{\circ}$

$V=1114.1(2) \AA^{3}$

$Z=4$

$D_{x}=1.230 \mathrm{Mg} \mathrm{m}^{-3}$

$D_{m}$ not measured
Mo $K \alpha$ radiation

$\lambda=0.7093 \AA$

Cell parameters from 25 reflections

$\theta=7.2-13.6^{\circ}$

$\mu=0.069 \mathrm{~mm}^{-1}$

$T=293 \mathrm{~K}$

Plate

$0.4 \times 0.3 \times 0.3 \mathrm{~mm}$

Colorless

\section{Data collection}

Nonius CAD-4 diffractometer

$\omega$ scans

Absorption correction: none

2033 measured reflections

1958 independent reflections 1622 reflections with

$$
I_{\text {net }}>2 \sigma\left(I_{\text {net }}\right)
$$

\section{Refinement}

Refinement on $F$

$R=0.035$

$w R=0.042$

$S=2.03$

1621 reflections

146 parameters

$\mathrm{H}$ atoms: see below

$w=1 /\left[\sigma^{2}(F)+0.0002 F^{2}\right]$

$(\Delta / \sigma)_{\max }<0.001$

$$
\begin{aligned}
& R_{\mathrm{int}}=0.012 \\
& \theta_{\max }=25^{\circ} \\
& h=-12 \rightarrow 12 \\
& k=0 \rightarrow 7 \\
& l=0 \rightarrow 20 \\
& 3 \text { standard reflections } \\
& \quad \text { frequency: } 120 \text { min } \\
& \text { intensity decay: none }
\end{aligned}
$$

$\Delta \rho_{\max }=0.14$ e $\AA^{-3}$

$\Delta \rho_{\min }=-0.15{\mathrm{e} \AA^{-3}}^{-3}$

Extinction correction: Larson (1970)

Extinction coefficient: $1.10(11)$

Scattering factors from International Tables for $X$-ray Crystallography (Vol. IV)

Table 2. Selected geometric parameters $\left(\AA,^{\circ}\right)$ for (II)

$\begin{array}{llll}\mathrm{C} 2-\mathrm{C} 3 & 1.377(2) & \mathrm{C} 9-\mathrm{C} 9 \mathrm{a} & 1.5149(18) \\ \mathrm{C} 4 \mathrm{a}-\mathrm{C} 9 \mathrm{a} & 1.3986(18) & \mathrm{C} 9-\mathrm{C} 12 & 1.5553(19) \\ \mathrm{C} 4 \mathrm{a}-\mathrm{C} 10 & 1.5142(18) & \mathrm{C} 10-\mathrm{C} 10 \mathrm{a} & 1.5051(19) \\ \mathrm{C} 6-\mathrm{C} 7 & 1.380(3) & \mathrm{C} 10-\mathrm{C} 11 & 1.5520(19) \\ \mathrm{C} 8 \mathrm{a}-\mathrm{C} 9 & 1.5084(17) & \mathrm{C} 11-\mathrm{C} 12 & 1.5380(19) \\ \mathrm{C} 8 \mathrm{a}-\mathrm{C} 10 \mathrm{a} & 1.3978(19) & & \\ \mathrm{C} 4-\mathrm{C} 4 \mathrm{a}-\mathrm{C} 10 & 126.81(12) & \mathrm{C} 4 \mathrm{a}-\mathrm{C} 9 \mathrm{a}-\mathrm{C} 9 & 113.20(11) \\ \mathrm{C} 9 \mathrm{a}-\mathrm{C} 4 \mathrm{a}-\mathrm{C} 10 & 112.84(11) & \mathrm{C} 4 \mathrm{a}-\mathrm{C} 10-\mathrm{C} 10 \mathrm{a} & 107.55(10) \\ \mathrm{C} 8-\mathrm{C} 8 \mathrm{a}-\mathrm{C} 9 & 126.83(12) & \mathrm{C} 4 \mathrm{a}-\mathrm{C} 10-\mathrm{C} 11 & 106.18(10) \\ \mathrm{C} 9-\mathrm{C} 8 \mathrm{a}-\mathrm{C} 10 \mathrm{a} & 112.87(11) & \mathrm{C} 10 \mathrm{a}-\mathrm{C} 10-\mathrm{C} 11 & 106.84(11) \\ \mathrm{C} 8 \mathrm{a}-\mathrm{C} 9-\mathrm{C} 9 \mathrm{a} & 107.69(10) & \mathrm{C} 5-\mathrm{C} 10 \mathrm{a}-\mathrm{C} 10 & 126.53(12) \\ \mathrm{C} 8 \mathrm{a}-\mathrm{C} 9-\mathrm{C} 12 & 106.38(10) & \mathrm{C} 8 \mathrm{a}-\mathrm{C} 10 \mathrm{a}-\mathrm{C} 10 & 113.46(11) \\ \mathrm{C} 9 \mathrm{a}-\mathrm{C} 9-\mathrm{C} 12 & 106.50(10) & \mathrm{C} 10-\mathrm{C} 11-\mathrm{C} 12 & 109.80(11) \\ \mathrm{Cl}-\mathrm{C} 9 \mathrm{a}-\mathrm{C} 9 & 127.03(12) & \mathrm{C} 9-\mathrm{C} 12-\mathrm{C} 11 & 109.50(10)\end{array}$

$\mathrm{H}$ atoms were located by difference Fourier techniques and refined to reasonable positions during the early stages of refinement, but were fixed for the subsequent refinements.

For both compounds, data collection: $C A D-4-P C$ Software (Enraf-Nonius, 1993); cell refinement: CAD-4-PC Software; data reduction: DATRD2 in NRCVAX (Gabe et al., 1989); program(s) used to solve structures: SOLVER in NRCVAX; program(s) used to refine structures: $L S T S Q$ in NRCVAX; molecular graphics: ORTEPII (Johnson, 1976) in NRCVAX; software used to prepare material for publication: TABLES in NRCVAX (version of January 1994).

Support from the CSU College of Graduate Studies is gratefully acknowledged.

Supplementary data for this paper are available from the IUCr electronic archives (Reference: FR 1160). Services for accessing these data are described at the back of the journal.

\section{References}

Baldridge, K. K., Battersby, T. R., VernonClark, R. \& Siegel, J. S. (1997). J. Am. Chem. Soc. 119, 7048-7054.

Benites, M. del R., Maverick, A. W. \& Fronczek, F. R. (1997). Acta Cryst. C53, 1334-1335.

Cimarusti, C. M. \& Wolinski, J. (1968). J. Am. Chem. Soc. 90, 113120. 
Enraf-Nonius (1993). CAD-4-PC Software. Version 1.2. EnrafNonius, Delft, The Netherlands.

Gabe, E. J., Le Page, Y., Charland, J.-P., Lee, F. L. \& White, P. S. (1989). J. Appl. Cryst. 22, 384-387.

Garcia-Garibay, M., Scheffer, J. R., Trotter, J. \& Wireko, F. C. (1988). Tetrahedron Lett. 29, 1485-1488.

Johnson, C. K. (1976). ORTEPII. Report ORNL-5138. Oak Ridge National Laboratory, Tennessee, USA

Larson, A. C. (1970). Crystallographic Computing, edited by F. R. Ahmed, S. R. Hall \& C. P. Huber, pp. 291-294. Copenhagen: Munksgaard.

Mayo, D. W., Pike, R. M. \& Butcher, S. S. (1989). Microscale Organic Laboratory, pp. 189-192. New York: Wiley.

Miller, R. G. \& Stiles, M. (1963). J. Am. Chem. Soc. 85, 1798-1800.

Trotter, J. \& Wireko, F. C. (1990). Acta Cryst. C46, 103-106.

Acta Cryst. (1999). C55, 239-241

\section{Two (Z)-3-aryl(alkyl)ideneisoindolin-1-ones}

Nitya G. Kundu, ${ }^{a}$ M. Wahab Khan, ${ }^{a}$ SubHadra GuHA ${ }^{b}$ AND AloK K. MuKherJeE ${ }^{b}$

${ }^{a}$ Department of Organic Chemistry, Indian Association for the Cultivation of Science, Jadavpur, Calcutta 700 032, India, and ${ }^{b}$ Department of Physics, Jadavpur University, Calcutta 700 032, India. E-mail: akm@juphys.ernet.in

(Received 5 May 1998; accepted 24 July 1998)

\begin{abstract}
Two isoindolin-1-one derivatives, $(Z)-3$ - $(p$-methoxybenzylidene)isoindolin-1-one $\left[\mathrm{C}_{16} \mathrm{H}_{13} \mathrm{NO}_{2},(2)\right]$ and $(Z)$ 3-(2-hydroxy-2-methylpropylidene)- $N$-( $p$-tolyl)isoindolin1-one $\left[\mathrm{C}_{19} \mathrm{H}_{19} \mathrm{NO}_{2},(3)\right]$, were synthesized by palladiumcatalyzed hetero-annulation. The molecules of both compounds, which have a $Z$ configuration, contain two planar parts, namely, the isoindolinone moiety and the phenyl ring. The r.m.s. deviation $(0.111 \AA)$ from the least-squares plane through the non- $\mathrm{H}$ atoms in compound (2) illustrates the overall molecular planarity. In (3), the phenyl ring is twisted out of the isoindolinone plane by $79.8(1)^{\circ}$. Intermolecular hydrogen bonds link the molecules in (2) and (3) into infinite onedimensional chains.
\end{abstract}

\section{Comment}

The isoindolinones (phthalamidines) form an important class of biologically important organic compounds (Fuska et al., 1985) and exhibit a close structural similarity to bioactive indoles. As part of our on-going study of isoindolinone-containing heterocyclic systems of biological importance, we have reported recently the crystal structure of $(Z)-N$-benzyl-3-benzylideneisoindolin-1-one [(1); Khan et al., 1998] prepared via a palladium-catalyzed reaction between $\mathrm{N}$-benzyl-o-iodobenzamide and phenylacetylene. We describe here the crystal structures of two additional examples, namely, (Z)-3-( $p$-methoxybenzylidene)isoindolin-1-one, (2), and (Z)-3-(2-hydroxy-2-methylpropylidene)- $N$-( $p$-tolyl)isoindolin-1-one, (3).

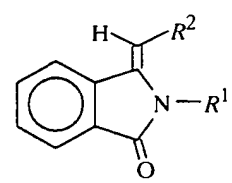

(1) $R^{1}=\mathrm{CH}_{2} \mathrm{Ph} ; R^{2}=\mathrm{Ph}$

(2) $R^{1}=\mathrm{H} ; R^{2}=\mathrm{C}_{6} \mathrm{H}_{4}-p-\mathrm{OMe}$

(3) $R^{1}=\mathrm{C}_{6} \mathrm{H}_{4}-p-\mathrm{Me} ; R^{2}=\mathrm{CHC}(\mathrm{OH}) \mathrm{Me}_{2}$

The bond distances and angles observed in (2) and (3) are similar to those reported for substituted isoindoline structures (Khan et al., 1998; McNab et al., 1997; Barrett et al., 1996; Feeder \& Jones, 1996). The $Z$ configurations of the molecules of (2) and (3), which contain essentially planar isoindolinone and phenyl moieties, are established by the torsion angle $\mathrm{N}-\mathrm{C} 8-\mathrm{C} 9-\mathrm{C} 10$ of $0.6(3)^{\circ}$ in (2) and $\mathrm{N}-\mathrm{C} 7-$ $\mathrm{C} 16-\mathrm{C} 17$ of $-2.7(8)^{\circ}$ in (3). The phenyl ring is twisted out of the isoindolinone plane (atoms $\mathrm{C} 1-\mathrm{C} 8$ ), with dihedral angles of $12.4(1)$ and $79.8(1)^{\circ}$ in (2) and (3), respectively. The overall molecular planarity in (2) (r.m.s. deviation $0.111 \AA$ ) strongly suggests a resonance interaction extending over the $\mathrm{C} 9$ atom. This is reflected in a significant shortening of the C9-C10 bond length [1.437(2) $\AA$ ] in (2) compared with the $\mathrm{C} 16-\mathrm{C} 17$ bond [1.507 (4) $\mathrm{A}]$ in (3) or with the expected $\mathrm{C}_{a r y l}-\mathrm{C}_{s p^{2}}$ distance. The exocyclic bond angles around atoms C8 [in (2)] and C7 [in (3)] are highly asymmetric, with the $\mathrm{N}-\mathrm{C} 8-\mathrm{C} 9$ [in (2)] and $\mathrm{N}-\mathrm{C} 7-\mathrm{C} 16$ [in (3)] angles being markedly larger than the other angles. Intermolecular hydrogen bonds $[\mathrm{N}-$

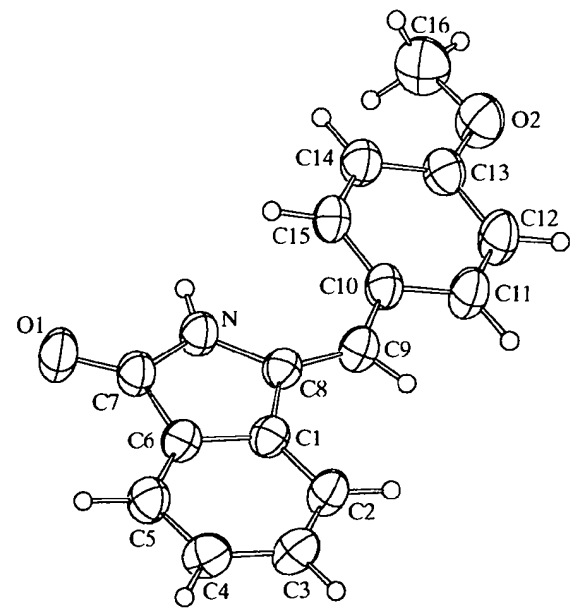

Fig. 1. ORTEPII (Johnson, 1976) view (50\% probability level) of (2). 